\title{
An empirical study on performance-based payment systems: A case study of economical and non-economical organizations
}

\author{
Somaye Bahrami ${ }^{\mathbf{a}^{*}}$, Hossein Naderi ${ }^{\mathrm{b}}$ and Saman Mosanezhad ${ }^{\mathrm{c}}$
}

${ }^{a}$ Department of accounting, Islamic Azad University- Borojerd Branch, Lorestan, Iran

${ }^{b}$ Department of accounting, Islamic Azad University- Ilam Branch, Ilam, Iran

${ }^{c}$ Department of accounting, University of Applied Science and Technology-Ilam Branch-Ilam, Iran

\begin{tabular}{l}
\hline A R T I C L E I N F O \\
\hline Article history: \\
Received March 25, 2012 \\
Received in Revised form \\
April, 15, 2012 \\
Accepted 22 May 2012 \\
Available online \\
May 27 2012 \\
\hline Keywords: \\
Performance-based payment \\
Payment system \\
Work experience \\
Educational background
\end{tabular}

\section{A B S T R A C T}

In this paper, we propose an empirical survey between two groups of people who work for two types of governmental organizations asking them whether they prefer to receive their salaries based on their personal characteristics such as job experience, educational background and job performance. The results of our experience indicate that the people who participated in our survey mostly believe that the payment must be performed based on their performance and those who could contribute more must be entitled more in terms of their salaries. The preliminary results of our survey indicate that the payment system must be based on the level of education; work experiences and ob performance. In addition, the people who participate in our survey mostly believe that a transparent policy in payment system helps employees increase their motivation.

(c) 2012 Growing Science Ltd. All rights reserved.

\section{Introduction}

One of the most important principles of all governmental agencies is to design a fair payment system. In many countries, there have been tremendous efforts on proposing a comprehensive method for such systems. Nevertheless, there are still many places with no unique and fair payment system and employees are still suffering from the effects of unfair payment systems. When there is no transparent payment system, it is getting difficult to create motivation among employees to work hard. In such event, one alternative solution is to propose promotion plans for those who work harder and contribute more to work (Milkovich \& Wigdor, 1991; Denton, 1991; Mirabella, 1999; Chiang \& Birtch, 2010). Taylor (1911) is believed the first who stated that those employees who receive payment based on their performance work harder (Mayo, 1933). There are many studies on performance payment based systems and some of these studies indicate that these payment systems increase employees' performance (Lawler, 1971, 2000, 2005).

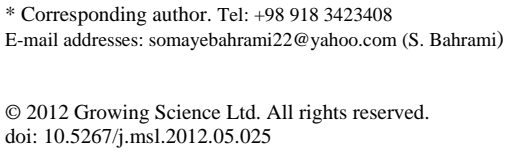


On the other hand, this payment system makes a clear distinction between employees with high performance and other employees. There are also some studies, which indicate that this type of payment system increases job satisfaction. In other studies, there is a direct relationship between employees' perception and job satisfaction (Carroll \& Tosi, 1973; Neuman, 1994; Robbins, 2004). In this paper, we present an empirical study to measure the impact of different factors on employees' interest in their jobs. According to Bateman and Snell (2004), the employees who receive payment based on their performance tend to do their responsibilities more carefully. Serneels (2008) reported that education is important for the allocation to job levels and based on some data on cognitive ability, Serneels explained that the impact of education on wages is at least partially because it signals cognitive ability but the survey results evidenced that the returns to education were not associated with performance.

Yeh et al. (2009) explained that performance-based pay systems, also known as variable pay systems, are commonly used in workplaces as a business strategy to increase workers' performance and reduce labor expenditures and they investigated the influence on workers' job stress and stress-related health outcomes. They used data from a nationally representative sample of paid workers in Taiwan and studied the distribution of variable pay systems across socio-demographic categories and employment sectors. They reported that among the three pay systems, employees' earning through a performancebased pay were suffering from the longest working hours, the highest level of job control, and the highest percentage of workers who received high stress at work. The results of multivariate regression analyses indicated that workers earning through performance-based and piece-rated pay systems had higher scores for personal burnout and work-related burnout, as compared with those who were given fixed salaries. Chiang and Birtch (2010) investigated the mediating impacts of employeeorganization service value congruence on pay for performance and work attitudes. They used a sample drawn from the hotel industry and found that when employees perceived a high PFP link they tended to exhibit more positive work attitudes. They reported that the relationship between PFP link and work attitudes was mediated by $\mathrm{P}-\mathrm{O}$ fit.

\section{The proposed model}

Consider two groups of people who work for economical and non-economical agencies. Let A and B be two groups who work for these two groups, respectively and we want to study in their interests in payment system based on performance. The following hypothesis are investigated in this paper,

1. There is a meaningful difference between employees' interest in group A and B.

2. There is a meaningful difference between low and high experienced employees' interest in group A and B in terms of considering their job experiences for payment system.

3. There is a meaningful difference between low and high experienced employees' interest in group A and B in terms of considering their performance for payment system.

4. There is a meaningful difference between low and highly educated employees' interest in group A and B in terms of considering their educational backgrounds for payment system.

5. There is a meaningful difference between low and highly educated employees' interest in group A and B in terms of considering their performance for payment system.

6. There is a meaningful difference between employees' interest in group A and B in terms of their job experiences, education background and performance for payment system.

7. There is a meaningful difference between employees' interest in group A and B with different gender in terms of their job experiences, education background and performance for payment system.

The proposed study of this paper considers 1560 employees who work for economical agencies including Tax, Business, Economics and Finance and Audit Court and non-economical organizations including two universities and one welfare organization. Therefore we could use the following formula to calculate the minimum number of sample size, 


$$
n=\frac{N \times z_{\alpha / 2}^{2} \times p \times q}{\varepsilon^{2} \times(N-1)+z_{\alpha / 2}^{2} \times p \times q},
$$

where $N$ is the population size, $p=1-q$ represents the yes/no categories, $z_{\alpha / 2}$ is CDF of normal distribution and finally $\varepsilon$ is the error term. Since we have $p=0.5, z_{\alpha / 2}=1.96$ and $N=1560$, the number of sample size is calculated as $n=175$. We have distributed 175 questionnaires among them where 43 questionnaires were distributed among those who worked for economical agencies and 132 were distributed among those who were the employees of non-economical agencies. In terms of their genders, 95 were male and the remaining 80 people were female. Table 1 demonstrates their educational backgrounds.

Table 1

Educational background

\begin{tabular}{lllllllll}
\hline Years of education & 5 & 8 & 12 & 14 & 16 & $>=18$ & No response & Total \\
\hline Freq. & 2 & 3 & 19 & 30 & 93 & 26 & 2 & 175 \\
Percentage & 1.1 & 1.7 & 10.9 & 17.1 & 53.1 & 14.9 & 1.1 & 100 \\
Acc. Freq. & 1.1 & 2.8 & 13.7 & 30.8 & 83.9 & 98.9 & 100 & \\
\hline
\end{tabular}

\section{The results}

In this section, we present details of our survey using t-student and ANOVA tests for one main hypothesis and six sub-hypotheses. Table 2 shows details of our t-student tests.

\section{Table 2}

The results of t-student test

\begin{tabular}{|c|c|c|c|c|c|}
\hline \multicolumn{2}{|c|}{ Hypothesis Independent variable } & Dependent variable & Sig. & P-value & Result \\
\hline Main & Employee & $\begin{array}{l}\text { Payment based on } \\
\text { performance }\end{array}$ & 0.05 & 0.00 & $\begin{array}{l}\mathrm{H}_{1} \\
\text { accepted }\end{array}$ \\
\hline \multicolumn{6}{|l|}{ Sub. } \\
\hline 1 & $\begin{array}{l}\text { Low and high experienced employees' interest in } \\
\text { paying based on work experience }\end{array}$ & Payment system & 0.05 & 0.02 & $\begin{array}{l}\mathrm{H}_{1} \\
\text { accepted }\end{array}$ \\
\hline 2 & $\begin{array}{l}\text { Low and high experienced employees' interest in } \\
\text { paying based on performance }\end{array}$ & Payment system & 0.05 & 0.0426 & $\begin{array}{l}\mathrm{H}_{1} \\
\text { accepted }\end{array}$ \\
\hline 3 & $\begin{array}{l}\text { Educated employee's interest in paying based on } \\
\text { education }\end{array}$ & Payment system & 0.05 & 0.001 & $\begin{array}{l}\mathrm{H}_{1} \\
\text { accepted }\end{array}$ \\
\hline 4 & $\begin{array}{l}\text { Educated employee's interest in paying based on } \\
\text { performance }\end{array}$ & Payment system & 0.05 & 0.0292 & $\begin{array}{l}\mathrm{H}_{1} \\
\text { accepted }\end{array}$ \\
\hline 5 & Performance, education and work experience & Payment system & 0.05 & 0.00 & $\begin{array}{l}\mathrm{H}_{1} \\
\text { accepted }\end{array}$ \\
\hline 6 & $\begin{array}{l}\text { Gender influence between employees who work } \\
\text { for two organizations }\end{array}$ & $\begin{array}{l}\text { Performance, } \\
\text { education and work } \\
\text { experience }\end{array}$ & 0.05 & 0.000 & $\begin{array}{l}\mathrm{H}_{1} \\
\text { accepted }\end{array}$ \\
\hline
\end{tabular}

As we can observe from the results of Table 2, we understand that there are enough evidences to reject the null hypothesis coming to conclusion that employees are interested in payment based on performance. In other words, the main hypothesis is confirmed when the significance level is five percent. The results of Table 2 also confirm all six sub-hypothesis when the level of significance is five percent. Therefore, the first sub-hypothesis indicates that there is a meaningful difference between people with low and high levels of job experience in terms of considering payment based on work experience. The second sub-hypothesis indicates that there is a meaningful difference between people with low and high levels of job experience in terms of considering payment based on their performance. The third sub-hypothesis indicates that there is a meaningful difference between people with low and high levels of educational level in terms of considering payment based on their 
educational backgrounds. Note that in this study, we consider people with at least a bachelor degree as highly educated people. The fourth sub-hypothesis indicates that there is a meaningful difference between people with high level of educations and the people with low level of educations in terms of considering payment based on their educational backgrounds. The fifth sub-hypothesis indicates that there is a meaningful difference between people with different levels of job experience, educations and performance for payment based on these items. Finally, sub-hypothesis indicates that there is a meaningful difference between people's genders with different levels of job experience, educations and performance for payment based on these items.

\section{Conclusion}

In this paper, we have presented an empirical survey between two groups of people who worked for two types of governmental organizations and asked them whether they preferred to receive their salaries based on their different characteristics such as job experience, educational background and performance or not. The results of our experience indicate that the people who participated in our survey mostly believed that the payment must be performed based on their performance and those who could contribute more must be entitled more in terms of their salaries. One moral story from the summary of our survey is that the payment system must be arranged to pay more to those employee with high level of educations, work experiences, and maintain high level of performance. Finally, our surveyed people believed that a transparent policy in payment system could help employee increase their motivation to contribute more.

\section{References}

Carroll, S.J., \& Tosi, H.L. (1973). Management by Objectives: Applications and Research. New York: Macmillan.

Lawler ,E ( 1971). Pay and Organizational Effectiveness: A psychological view. New York, McGraw-Hill.

Lawler, E. (2000). Rewarding Excellence: Pay Strategies For the New Economy. San Francisco: Jossey-Bass Inc .

Lawler, E. (2005). New Loyalty. Leadership Excellence, 22 (3), 14-15.

Chiang, F.F.T., \& Birtch, T.A. (2010). Pay for performance and work attitudes: The mediating role of employee-organization service value congruence. International Journal of Hospitality Management, 29(4), 632-640

Mirabella, J. W. (1999). Employee preferences for pay systems as a function of personal job inputs and job characteristics. unpublished doctoral dissertation, Nova southeastern university.

Denton, D.K. (1991). What's wrong with these employees? Business Horizons, 34 (5), 45-50.

Bateman, T. S., \& Snell, S. A . (2004). Management: The new Competitive Landscape. $6^{\text {th }}$ Ed . New York : McGraw.

Milkovich, G. T., \& Wigdor, A. K. (1991). Pay for performance: Evaluating performance appraisal and merit pay. The National Academy Press.

Taylor, F. (1911). The Principles of Scientific Management. New York: Harper \& Row.

Neuman, W.L. (1994). Social Research Methods: Qualitative and Quantitative Approaches. $2^{\text {nd }}$ Ed., Boston: Allyn \& Bacon.

Robbins, S.P. (2004). Organizational behavior. $10^{\text {th }}$ Ed. Upper Saddle River, NJ: Prentice-Hall Inc.

Serneels, P. (2008). Human capital revisited: The role of experience and education when controlling for performance and cognitive skills. Labour Economics, 15(6), 1143-1161.

Yeh, W.Y., Cheng, Y., \& Chen, C.J. (2009). Social patterns of pay systems and their associations with psychosocial job characteristics and burnout among paid employees in Taiwan. Social Science \& Medicine, 68(8), 1407-1415. 